\title{
China-Gulf Relations for the Period 2001-2018
}

\author{
Mazin Qasim Mhalhal \\ University of Baghdad, Baghdad, Iraq
}

\begin{abstract}
China is one of the major powers and this position makes it open to various countries of the world, including the Gulf States. The China-Gulf relations have witnessed progress in various fields, but trade and energy have been the most important areas of cooperation between the two sides. The importance of researching the substance of relations between China and the Gulf States imposes itself on the size of China's political, military, and economic, and the weight of the Gulf financial and energy. The aim of the research is to diagnose the relations between the two sides at the political and economic levels, during the period between 2001 and 2018. The research deals with a problem that is shaped by a research question: Why did China-Gulf relations between 2001 and 2018 in the way it appear? Which raises the need to answer several questions, including: What are the political relations between China and the Gulf countries? What are the economic relations between China and the Gulf countries? This problem prompts us to adopt the premise of its content: The relations between China and the Gulf have taken into consideration developments in various aspects, so we have seen remarkable growth in their economic and political exchanges since the new millennium. The relations between China and the countries of the Gulf region have tended to develop politically and economically. China has not developed unilateral relations among the countries bordering the Arabian Gulf, that is, it has not developed relations with one country or two countries of the Arabian Gulf, but to all Gulf countries. This problem and hypothesis lead us to adopt a scientific approach to dealing with the content of the research, and we adopted here the analytical approach to verify the validity of the hypothesis adopted. As for the mutual investment between the two sides, it is clear that there is Chinese activity to expand Chinese investments in this region. China invested about $\$ 2$ billion in the Gulf Cooperation Council (GCC) countries in 2005, and the volume of investments is expanding annually to reach about $\$ 40$ billion in activities and fields, such as economic development. While the volume of Chinese investment in Iran reached about \$11 billion in 2017, Iran is the first country in which China invested in early 2000 when it invested about $\$ 2$ billion, and then expanded its investments later, taking advantage of the withdrawal of Western companies from the market Iran GCC investments in China widened after 2001 due to fears of protecting Gulf assets in Western countries and in the United States in particular. Gulf investors began pumping \$1.3 billion in 2002. The volume of investments in the GCC countries in China reached about $\$ 39.2$ billion in 2017.
\end{abstract}

Keywords: China-Gulf relations, payment of China, Arab cooperation building belt and road

\section{Introduction}

This problem and hypothesis led us to adopt a scientific approach to dealing with the content of the research, and we adopted here the analytical approach to verify the validity of the hypothesis adopted.

To address these relations, we will refer to two contents: political relations and economic relations.

Mazin Qasim Mhalhal, Ph.D. candidate, College of Political Science, University of Baghdad, Baghdad, Iraq. 


\section{Political Relations}

Political relations are one of the most important relations in the international system, because they refer to the content of the relationship (the existence of cooperation, tension, or conflicts in the relationship) between the two countries.

The relationship between China and the Gulf states shows that relations have gradually developed in recent decades. Although relations have historical roots in $\mathrm{BC}$, most countries in the region today were politically founded in the mid-20th century, in a circumstance dominated by Western powers. Most are the international relations, including the dominance of the Gulf region, while China's attention was focused on the East and Southeast Asia.

The Iraqi State emerged in $3600 \mathrm{BC}$, but modern Iraq emerged in 1921. Iran established its first dynasty in the Medes in 625 BC. Iran was founded in 1925. Saudi Arabia established its first emirate in 1744, The third was in 1926, and its foundation was the result of the vacuum left by the fall of the Arab Islamic state, while Oman was founded in 1145 AD. The modern state was founded in 1744; the rest of the Gulf United Arab Emirates emerged in the second half of the 20th century (Al-Haristani, 2005).

While China appeared in $2070 \mathrm{BC}$, the modern state appeared in $1911 \mathrm{AD}$, and represents a historical extension of it (Huakham, 2002).

After the founding of the People's Republic of China in 1949, China's interests were of several priorities in its foreign relations, the most important of which were the organization of relations with the Soviet Union, the opening up of East and Southeast Asia.

The Gulf Arab Emirates were linked to Britain and then linked to the United States. They did not open up to relations with China until 1971 when they exchanged diplomatic recognition with Kuwait, Oman in 1978, the UAE in 1984, Qatar in 1988, Bahrain in 1989, and Saudi Arabia in 1990.

The relations between China and the Middle East countries began since the founding of the People's Republic of China (PRC) in 1949. Iraq and Iran are among the most prominent countries that dealt with Iraq. The first stage of the transition of government in Iraq was from the monarchy to the republic in 1958 until 1978. The period of China's economic reforms and the beginning of China's opening to the world, was the same period in which Iraq was exposed to wars and crises, such as its war with Iran and its invasion of Kuwait and the economic embargo imposed by the United Nations until 2002/2003, as witnessed relations between the two countries at this stage had a remarkable development on all levels of political, economic, and military.

China began its first steps by consolidating the pillars of state rule and its people with the founding of the People's Republic of China in 1949.

The PRC's founding date can be marked as the beginning of China's drive to establish relations with the Middle East and North Africa, where China officially established these relations after the Bandung Conference in April 1955.

The first years of relations between Iraq and China were marked by differences of ideological thought. China followed the communist ideology, while Iraq, under the Baghdad Charter, joined the US-led anti-communist Western coalition (Makhieber, 2008).

Dr. Liu Zhongmin of the Institute of Middle East Studies at the Shanghai University of International Studies analyzed the content of the Gulf-China relations in the first decade of the 21st century to say: "At the 
beginning of the twenty-first century, attacks $11 / 9$ and the Iraq war have profound implications in the international system and in the Gulf region" (Liu, 2016, p. 66).

Therefore, the international and regional environment of Gulf-China diplomacy has become increasingly complex while the speed of modernization in China and the requirements of energy have become the driving force of internal adjustments in nature diplomacy between China and the Gulf states during this period. China's main context in the Gulf region has included deepening strategic cooperation with Saudi Arabia and the rest of the Gulf Cooperation Council (GCC), developing energy cooperation with Iran, participating in Iran's nuclear negotiations, and balancing its relations with the United States. Following the radical changes in the international situation and regional patterns, Saudi-Chinese interests converged in the enforcement and deepening of bilateral strategic cooperation, and after Abdullah Bin Abdul Aziz became king of the country, the strategic cooperation between the two countries accelerated to China in January 2006, followed by Chinese President Hu Jintao's visit to Saudi Arabia in April 2006 and February 2009, and Saudi Arabia is the largest oil supplier to China since 2009. In July 2004, the Secretary-General of the Gulf Cooperation Council Member States China signed the Framework Agreement on Economy, Trade, and Investment and the negotiations on a free trade agreement were announced. In June 2010, the strategic dialogue mechanism between China and the GCC countries was developed and the first round was held in Beijing. On the issue of US military intervention in Iraq, China opposed US decision-making while it did not want to be seen as the leader of the anti-US camp.

After the war ended, China supported the reconstruction of Iraq through the development of relations, economic and commercial sectors, and encouraging Chinese companies to invest in Iraq. China canceled $80 \%$ of Iraq's debts. As for Sino-Iranian relations and the nuclear issue, China has tried to strike a balance between its relations with the United States and Iran and to protect its economic interests in Iran. It stressed three basic principles:

(1) Iran should not insist on the development of nuclear weapons;

(2) The international community should not resolve the Iranian nuclear issue by force;

(3) The Iranian nuclear issue must be resolved through peaceful talks.

The main position of China on this issue is to emphasize the international commitment to the non-proliferation regime and the positive reinforcement of the comprehensive cooperation between Iran and the IAEA, resolving the nuclear issue through political dialogue and maintaining the normal development of China-Iran relations. Therefore, China has long considered solving the Iranian nuclear issue through diplomatic mediation of the United States and the European Union rather than resorting to the Security Council. China has tried to resolve the nuclear issue through the International Atomic Energy Agency (IAEA), negotiates through bilateral channels, and adopts a six-year plan to renegotiate Iran's nuclear issue. In order to avoid damaging China-Iran energy cooperation, Beijing faced many difficulties. For example, from 2006 to 2010, four resolutions were passed with US backing on the issue of sanctions against Iran by the Security Council. And because of China's adherence to its position, it excluded the contents and items that directly affect their economic interests in Iran, which led to an increase in tension between Beijing and Washington on the cooperation between China and Iran in the field of energy. The analysis of the contents of China-Gulf relations in general shows that China's relations with the countries of the region gradually developed in the 1990s and reached the current millennium. Since 1992, Arab-Chinese conferences have been held with the aim of seeking opportunities to maximize cooperation relations between the parties concerned. These meetings in the years 1992, 1997, 1998, and 1999, but under the pressure of the events of September 11, 2001 in the United States, 
and the pressure of the occupation of Iraq in 2003, saw those relations a kind of relative stagnation in political areas because of the strength of the American rush in the region. The end of January 2004 took that relationship is moving in a new direction as a result of China's initiative to develop these relations. Chinese President $\mathrm{Hu}$ Jintao paid a visit to the headquarters of the Arab League in Cairo on January 30, 2004. Amr Moussa, then Secretary-General of the League, met with the permanent delegates of the 22 member states of the League. On the establishment of the China-Arab Cooperation Forum, it issues a "Joint Statement on the Establishment of the China-Arab Cooperation Forum" which aims at promoting dialogue and cooperation and advancing development and progress. Between 2004 and 2018, eight summit meetings of the States concerned were held (Liu, 2016).

(1) The First Ministerial Meeting of the Forum on China-Arab Cooperation, held in Cairo in September 2004;

(2) The Second Ministerial Meeting of the Forum on China-Arab Cooperation, held in Beijing in May 2006;

(3) The Third Ministerial Conference of the Forum on Arab-China Cooperation in June 2008, held in Beirut;

(4) The Fourth Ministerial Conference of the Forum on China-Arab Cooperation in September 2010, held in Beijing;

(5) The Fifth Ministerial Conference of the Forum on China-Arab Cooperation in July 2012, held in Tunis;

(6) The Sixth Ministerial Conference of the China-Arab Cooperation Forum held in Beijing, in June 2014;

(7) The Seventh Session of the Ministerial Meeting of the Arab-China Cooperation Forum held in Doha, in May 2016;

(8) The Eighth Ministerial Conference of the Forum on China-Arab Cooperation, held in Beijing in July 2018 (People's Daily Online, 2018a).

The relations between the parties involved in the political arena, noting that China's relationship with the Gulf Cooperation Council countries remained in the political side does not carry many variables, to 2013 when China put forward the initiative: One Belt, One Road, and during the Sixth Ministerial Conference of the Forum on China-Arab Cooperation in Beijing in June (Chinese-Arab partnership in the construction of the Belt and Road Initiative), as well as the promotion of energy cooperation as the cornerstone of the first phase, the infrastructure and the facilitation of trade and investment as wings, and three areas technically advanced and modern, including nuclear energy and space and satellite new energies and new as areas in those relations, which shares the entry of China-Arab cooperation a new stage of comprehensive development. In other words, the Chinese proposal was not only for the GCC countries but also for cooperation within the framework of the Arab-Chinese relations in general. In June 2014, Kuwaiti Prime Minister Sheikh Nasser Al-Mohammad Al-Ahmad Al-Sabah visited China, met with President Xi Jinping and discussed with him ways to enhance Arab-China cooperation, focusing on Sino-Chinese cooperation. In November 2014, Emir of Qatar Sheikh Tamim bin Hamad Al Thani visited China and the two heads of state jointly announced the establishment of a strategic partnership between China and Qatar. In December 2015, Abu Dhabi Crown Prince Sheikh Mohammed bin Zayed Al Nahyan met on the sidelines of his visit to China and discussed ways to strengthen bilateral relations. Then, in January 2016, Chinese President Xi Jinping visited Saudi Arabia and Egypt and delivered a speech at the headquarters of the League of Arab States, explaining China's plan for what he called the "Middle East Governance", as well as introducing a new concept and strategy for China-Arab cooperation on the continuous visits to China, and planning together for strategic cooperation in the future (Sun, 2017).

To raise the level of bilateral relations to a comprehensive strategic partnership in 2006, with the UAE in 2012, and with Qatar in 2014, the bilateral relations have developed greatly and practical cooperation in all 
fields has achieved fruitful achievements. China attaches great importance to the development of the Chinese president is keen to work together with the UAE side to continue to expand and deepen the mutually beneficial cooperation between the two countries in all fields within the framework of building the belt and the road so as to promote the China-UAE relations to a higher level. Bilateral cooperation is in light of the growing strategic cooperation between the two countries, coordination and consultation on regional and international issues of common interest, in addition to the signing of cooperation agreements in a number of fields (Chen, 2011).

The use of force and calls on all parties resolves conflicts through political means and in a peaceful manner. China used its veto three times between 2012 and 2013 to veto UN Security Council resolutions on military intervention in Syria, sparking discontent among Gulf States.

In order not to misunderstand its position, China quickly explained its policy to the GCC countries and stepped up strategic cooperation in energy. In early 2012, the visit of Chinese Premier Wen Jiabao to Saudi Arabia, Qatar, and the UAE resulted in the progress of the strategic partnership between China and those countries and launched the so-called strategic dialogue between the two parties (Skynews, 2018).

In May 2011, the second round of this dialogue was held in the UAE capital, and in January 2014, the third round was held in Beijing. Secondly, China actively participated in the negotiations on the Iranian nuclear issue, and reached out to the various parties to reach a nuclear agreement in 2015.

China has adopted a vision of enhancing cooperation with the Gulf countries to include energy cooperation in the first place, cooperation in the construction of infrastructure, trade and investment facilities, high-tech fields, modern nuclear energy, and satellites and new energy as a new progress. In the field of knowledge, China stressed the importance of establishing the free trade agreement between Beijing and the Gulf Cooperation Council (GCC) and the participation of the Arab countries in the Asian Infrastructure Investment Bank, established in 2014 in Beijing (People's Daily Online, 2018b).

However, the security situation in the Gulf region is not optimistic. Due to the instability in Iraq and Yemen, the widespread proliferation of terrorist organizations, and the fierce geopolitical rivalries between Saudi Arabia and Iran, it makes China a political problem that needs to be addressed to balance its relations with Saudi Arabia and Iran. In achieving the interests of the people in the Gulf region, how to address cooperative-competitive relations with the United States is the long-term challenge of Gulf-China diplomacy (China-Arab Cooperation Forum, 2018a).

Dr. Liu Zhongmin of the Institute of Middle East Studies at Shanghai University of International Studies analyzed the content of post-Arab Gulf-China relations to say (China-Arab Cooperation Forum, 2018b).

Many facts have affected the regional situation in the Gulf region, including the revolutions of the Middle East, the reduction of the US strategic role in the Middle East, US-Iranian relations, the situation of Iraq, the rise of a pro-Syrian organization, the outbreak of the Yemeni crisis, etc. Based on these conditions, Beijing has reduced its main points of contact in the Gulf-China diplomacy to deal with the impact East Disorders on the Gulf-China relations, and actively participated in the Iranian nuclear talks. In 2012, a new generation of Chinese leaders, President Xi Jinping, was elected.

Therefore, China's diplomacy became more proactive. In 2013, the president put forward the Chinese initiative (One Belt, One Road), China believes that this initiative will bring tremendous opportunities for the development of Gulf-China (Cai, 2017).

The use of force and calls on all parties resolves conflicts through political means and in a peaceful manner. China used its veto three times between 2012 and 2013 to veto UN Security Council resolutions on military intervention in Syria, sparking discontent among Gulf states (Xinhuanet, 2018). 
In order not to misunderstand its position, China quickly explained its policy to the GCC countries and stepped up strategic cooperation in energy.

In April 2017, the Center for Chinese-Arab Studies for Reform and Development was established at the Shanghai University of International Studies under the joint auspices of the Ministry of Foreign Affairs, the Ministry of Education, the Shanghai Municipal Government, and the Shanghai University of International Studies. The Center showed its interest in several topics, the most important of which are: economic development, governance experiences of China, and the potential for Arab countries to benefit from it.

In parallel with that meeting, the third session of the Strategic Political Dialogue was held at senior official level on international and regional issues of common concern. The first China-Arab Cooperation Forum for the BPDU (Bridge Protocol Data Unit) system was also held in Shanghai under the joint auspices of the China Satellite Navigation Satellite Administration Bureau, the Chinese Secretariat of the China-Arab Cooperation Forum, the League of Arab States Secretariat and the Arab ICT Organization for the establishment of a multi-term cooperation of China-Arab satellite navigation, and the enhancement of the service of the Baidu system for the Arab States, based on the adopted aspects of cooperation within the framework of the Cooperation Forum.

The second China-Arab Women's Forum was held in Beijing in September 2017. It included 150 government officials from China, Arab countries, the Arab League, the responsibilities of women's organizations, women's organizations, and representatives of Arab and Chinese academic and business circles. The forum discussed issues of women's empowerment and policy support in building initiative (One Belt, One Road), and others. The fifth session of the China-Arab Friendship Conference was held in Beijing under the joint auspices of the Chinese People's Friendship Association with Foreign Countries, the China-Arab Friendship Association, and the League of Arab States. The symposium was followed by the Chinese-Arab Forum for Reform and the development in Beijing organized by the Chinese Foreign Ministry to host the Center for Chinese-Arab Studies for Reform and Development, which discussed topics, such as sharing experiences of governance and state administration, achieving prosperity and common development, exploring the Chinese concept and the path of Arab development, and Arabic to build the belt and road (Makram Belawi, 2017).

Following the mechanisms upon which the Cooperation Forum was adopted, it includes three main mechanisms:

(1) The ministerial meeting (which is held every two years in China or at the headquarters of the Arab League or in one of the Arab countries alternately), which is a permanent mechanism to hold a regular meeting at the level of foreign ministers and secretary general of the Arab League. Unusual if necessary. The Ministerial Meeting will discuss means of enhancing cooperation between China and the Arab countries in the political, economic, and security fields, exchanging views on regional and international issues of common concern, as well as issues of importance in the meetings of international organizations, follow-up of the work program of the Forum and discuss other matters of mutual concern.

(2) The Senior Officials' Meeting (which is held annually and hosted by the two parties alternately), whose tasks are to prepare for the regular meetings of foreign ministers and follow up the implementation of recommendations and decisions on these meetings and holding high-level Arab-Arab strategic political consultations.

(3) The contact group, which will communicate between the two parties and follow up the implementation of the decisions and recommendations reached at ministerial level meetings and senior officials. These missions 
will be carried out by the Chinese Embassy in Egypt and the Chinese General Secretariat of the Forum on Arab-Chinese Cooperation in the Department of West Asia and North Africa at the Ministry of Foreign Affairs. The Council of Arab Ambassadors and the Arab League Mission in Beijing as the Arab body for communication. The task of both sides is to establish communication between the two parties and to follow up the implementation of the decisions and recommendations reached at the meetings Foreign Ministers and senior officials.

There are other mechanisms that have gradually emerged within the framework of the Arab-China Cooperation Forum, including the Businessmen's Conference, the China-Arab Relations Forum, the Sino-Arab Dialogue, the China-Arab Friendship Conference, the China-Arab Cooperation Conference in the field of Sino-Energy, the symposium on China-Arab media cooperation and the establishment of mutual cultural events, and the context in which these activities emerged is that it is held once every two years in China and one of the Arab countries alternately.

These mechanisms and the framework of the cooperation forum have contributed to a major development in Sino-Arab relations in general, including the relationship with the GCC countries. China's ambassador to Qatar, Li Zhen, said on September 24, 2018:

China is expanding its China will continue to need reform and opening up to complex and difficult conditions on the road to development, so it will continue to develop and develop its relations with China. Is now taking decisive steps in deepening reforms, China will continue to adhere to a peaceful approach to development, support multilateralism and push forward the building of international relations in a new style. (China-Gulf relations): China, which has medical relations with all the parties believe that maintaining stability and harmony in the Gulf region is an essential interest of their peoples, and always calls for maintaining peace and stability in the region and resolving disputes through dialogue and negotiation, so China called for a solution to the crisis through dialogue, mutual respect and non-interference in the internal affairs of others. Kuwaiti mediation is in the Gulf crisis. (Nibluk, 2017, pp. 81-82)

The important political point that China has focused on in all its Arab relations, including the Gulf, is the implementation of the one-belt (one-way) initiative, which aims to develop and establish trade routes and economic corridors linking China with more than 60 countries. The ancient Silk Road, a commercial road network passes through South Asia to connect China with the countries of South and East Asia and the Middle East to Turkey; the one-way refers to the sea route inspired by a cruise by the Chinese Admiral (Zheng Hee), who sailed a fleet of ships to Africa in the century the 15 th century $\mathrm{AD}$, and is a symbol of the originality of the Chinese navy. Through this initiative, China is trying to cement trade and economic ties between Asia, Europe, and Africa (The World Trade Organization, 2018).

The initiative includes the construction of rail, oil, and gas pipelines power lines, the Internet, and maritime infrastructure, enhancing China's connection to Europe and Africa. In terms of land, the initiative includes the construction of three corridors. They are:

(1) The first line connects East China, across Central Asia and Russia to Europe;

(2) The second line starts from China through central and western Asia and the Arabian Gulf to the Mediterranean;

(3) The third line extends from China through South-East Asia and South Asia to the Indian Ocean.

In addition, a number of land lanes built under the project, including a corridor linking China to South Asia, and another link to Pakistan, and another link to the province of Yunnan, southwest China, Burma, and Bangladesh (Faria, Mollick, Albuquerque, \& León-Ledesma, 2016). 
In other words, it is a network of corridors connecting Asia with Europe and Africa. The starting point of these corridors is China, and it also includes a land passage from China to the Arabian Gulf and the Mediterranean Sea (Alekhlna \& Naoyuki, 2018).

The first route starts from the Chinese coast through the Straits of Malacca to South Asia, the Middle East, East Africa, and the coast of Europe, and the second line connects Chinese ports to the South Pacific, connecting Chinese ports to the Pacific through the South China Sea and another corridor connecting Chinese ports to the Middle East, Africa, and Europe. The initiative aims at promoting dialogue, communication, and currency exchange, and strengthening economic and political relations. To implement the initiative, China has established an investment fund with a capital of 100 billion US dollars. Chinese President Xi Jinping has supported the financing of the initiative with an additional 14.5 billion dollars for the investment fund and 50 billion dollars in loans, $\$ 8.7$ billion in aid to developing countries and pledged to encourage financial institutions to expand financing activities to $\$ 43.5$ billion (Leung, Li, \& Low, 2011).

It has obtained general Arab approvals for the acceptance of the two initiatives, and cooperation has been included in them at the 7th meeting of the Arab-China Cooperation Forum in 2014.

Following the establishment of the China-Arab Cooperation Forum, high-level exchanges between China and the general Arab countries, including the GCC countries, have been strengthened, which have further enhanced mutual political trust and pragmatic cooperation. Saudi Arabia in 2006, with the UAE in 2012, Qatar in 2014, and the 2016 China policy document for Arab countries highlights the importance of the Arab region to China's policy ${ }^{1}$.

Among the most important conferences held under the framework of the Cooperation Forum, it was the Seventh Conference held in 2016 in Doha, in which the emphasis was placed on the implementation of plans of cooperation and achieving the goals behind the establishment of that forum, and despite the existence of some obstacles, such as the presence of the United States in the Arab region, the imbalance in the political and security stability in the region, the Chinese position on the Syrian events, and the crisis of the Iranian nuclear file that tends to intersect slightly with the general Arab position of those events and crisis, China is showing its supportive stance to the Arab countries in general on strengthening its territorial integrity and achieving comprehensive peace in the region. It is also working to develop its relations with the GCC countries at a great rate. Hormuz, the GCC states and other Arab countries supported China's position on Taiwan's peaceful reunification with China and supported China's position on the Doha 2016 Summit at the 7th Ministerial Meeting of the Forum on Sino-Arab Cooperation on Differences over the South China Sea. Unanimously expressed support for China's principled position, and stressed the need to respect the sovereignty of States and the settlement of the conflict within the framework of (the United Nations Convention on the Law of the Sea), and stay away from internationalization ${ }^{2}$.

Following the one-way road initiative, announced by Chinese President Xi Jinping in 2013 and adopted at the sixth session of the Ministerial Meeting of the China-Arab Cooperation Forum in June 2014, several steps have been taken to promote cooperation. The agreement was reached on the following: China-Arab partnership in the construction of the belt and road, the promotion of cooperation in energy, infrastructure, trade, and

\footnotetext{
${ }^{1}$ Relations between Saudi Arabia and China: From the Silk Road to the Oil Gate, Asharq Al Awsat Newspaper, No. 12888, dated March 12, 2014.

2 A report, a great reception for the Crown Prince in Beijing and a meeting with the Chinese President, Al-Awsadiya Newspaper, on March 13, 2014, at: http://www.aleqt.com/2014/03/13/article_832973.html.
} 
investment facilitation, and the agreement to enhance cooperation in three areas of advanced and modern technology, including nuclear energy, space, satellites, and new energies ${ }^{3}$.

The expansion of the relations, in light of the trend of China raised the ceiling of its import of energy, in 2016, the import of 144.3 million of liquefied natural gas (LNG) from the Arab countries, accounting for $19.9 \%$ of total imports; in 2017, the crude oil from the Arab countries, up to about $37.03 \%$ of the total imports, and the number of engineering contracts concluded in the field of oil industries with Arab countries about 32.8 billion dollars. The two sides have embarked on major projects, such as harmonization in production capacity, oil refining, port establishment, and other fields. China has established a center for technology transfer within the framework of the China-Arab Cooperation Forum, and the relevant parties in the forum have signed several agreements, including the establishment of the Nuclear Training Center for Peaceful Use of Nuclear Energy, the Clean Energy Center, and the Science and Technology Partnership Program. The space includes the UAE and Saudi Arabia.

China supported specific positions in the Arab region in general, including in the Gulf region. It supported the establishment of a nuclear-weapon-free zone in the Middle East and called for an urgent international conference to transform the Middle East into a zone free of weapons of mass destruction. China also works with those countries to promote exchanges and cooperation in the fight against terrorism, separatism, and extremism, establishes a long-term security cooperation mechanism, promotes political dialogue, and exchanges of information (Boukhamsin, 2017).

Development of technical cooperation and vocational training deals jointly with the risks of international and regional terrorism.

\section{Economic Relations}

Economic relations include several issues:

(1) Trading;

(2) Investment;

(3) Energy.

He added the theme of China's Belt and Road Initiative, an initiative aimed at raising the level of trade exchange between China and the countries that have ties under the initiative, as well as promoting political ties between these countries and China.

As for the trade between China and the Gulf countries, it is clear that the volume of trade between China and the GCC countries grew from about 6.9 billion dollars in 2000 (about 1.4\% of China's foreign trade) to about 103.8 billion dollars (about 3.49\% China's foreign trade), and reached about 132.9 billion dollars in 2017 (about $3.1 \%$ of China's foreign trade).

The volume of trade between China and Iran reached about 4.8 billion dollars in 2000 and about 3.9 billion dollars in 2010, to jump to about 31.9 billion dollars in 2017. Iran's exports to China include $26 \%$ of Iran's exported oil or about 600,000 barrels/day, petrochemical products, and various other products, while Chinese exports include various goods and services ${ }^{4}$.

China's economic ties with Iran have been noted. China has tried to exploit the Western withdrawal from Iran during the sanctions. About 100 major Chinese companies entered Iran's various economic sectors in 2009,

\footnotetext{
${ }^{3}$ Report: The first China in the trade exchange with Saudi Arabia, the site of satellite Arabic, on March 15, 2017, at the link: https://www.alarabiya.net.

4 Trade volume between UAE and China grew to $35 \%$ on October 4, 2018 at http://amwal-mag.com/.
} 
and 166 of them became major companies in 2011 (China International Network Website, 2018).

The volume of trade exchange between China and the Arab Gulf countries indicates a continuous rise and was not influenced by political events. However, two studies were relatively affected: low oil prices, which reduced the cost of Chinese imports between 2013 and 2016 and international sanctions against Iran between 2005 and 2015, increasing possibility of the volume of trade exchange between China and Iran during that period. The volume of trade exchanges between China and the Gulf countries can be tracked.

The pursuit of economic ties between China and the Arab Gulf countries shows that these relations are on the path of increasing the value of trade exchanges, although the predominance or value of exchanges related to the trade of energy resources is the biggest in economic relations between the two sides (Mohamed Building, 2018).

The value of the economic exchanges associated with the Chinese oil trade with the countries of the world (the volume of the cost of China's oil imports) is estimated at about $\$ 5.2$ billion in 2001 and 2009, \$217.5 billion in 2010, \$129.1 billion in 2011, \$139.7 billion in 2012, \$161.3 billion in 2013, \$118.9 billion in 2014, $\$ 112.2$ billion in 2015, \$97.6 billion in 2016, and 113.1 billion in 2017 (and fluctuation not in the quantities imported from oil but because of fluctuating prices). In 2007, China imported $\$ 0.5$ billion, $\$ 7.8$ billion in 2010, $\$ 15.2$ billion in 2015 , and $\$ 28.2$ billion in $2017^{5}$.

China's relations with the countries of the region, namely Saudi Arabia, the United Arab Emirates, and Iran, are related to Saudi Arabia's economic relations between the two countries. At the end of the last decade of the last century, Chinese President Jiang Zemin visited Saudi Arabia in 1999; followed by King Abdullah's visit the Saudi leadership has identified China as the most important strategic partner in the East Asian region. Saudi Arabia sees China as its first economic choice, particularly in the field of oil imports, and trade exchange is rising at a great rate. In 2000 , it reached about $\$ 2.9$ billion, in 2010 , about $\$ 51.4$ billion, then to reach about $\$ 70$ billion in 2013 , to about $\$ 57.8$ billion in 2015 , to $\$ 42$ billion in 2016 , and to $\$ 53$ billion in 2017 , and the other development came when the Chinese President Chi (When he was vice president) in 2008, during which he signed an agreement (the joint statement to enhance cooperation and strategic friendship between the People's Republic of China and Saudi Arabia).

As for the energy sector, as an economic activity specialized in these relations, it is clear that there is a high Chinese import of energy from the Gulf region, and since 2008, China has been moving to regulate the relationship with the Arab countries in the field of energy trade, cooperation in the field of energy within the framework of the Arab-China Cooperation Forum. Five sessions were held until 2016. The China-Arab Cooperation Forum held five joint conferences to discuss energy cooperation relations (Free Space, 2017).

(1) The First Session of the Conference on Energy Cooperation in January 2008;

(2) The Second Session of the Conference on Energy Cooperation in January 2010;

(3) The Third Session of the Conference on Energy Cooperation in September 2012;

(4) The Fourth Session of the Conference on Energy Cooperation in October 2014;

(5) The Fifth Session of the Conference on Energy Cooperation in October 2016.

Which includes the GCC states and Iraq? Energy relations with Iran were regulated by bilateral agreements.

\footnotetext{
5 Report: Chinese investments in the UAE recorded $\$ 9$ billion in 2017, Al Hayat Newspaper, on July 17, 2018, at: http://www.alhayat.com/article/4592640.
} 
The last point or theme of the "one-way-one-way" initiative, introduced by China in 2013, remains an important initiative aimed at strengthening economic relations with all Arab countries, including the GCC states and Iraq. China has put forward the initiative on this issue ${ }^{6}$ and devoted significant investments to it, in order to facilitate its access to the markets of the target countries and to strengthen the political link between those countries and China.

China has signed bilateral cooperation agreements on economic, trade, and technical cooperation with 22 Arab countries, including the Gulf Cooperation Council (GCC) countries, which has helped to raise the level of trade exchanges between the two parties after experiencing some of the decline between 2012 and 2015 for various reasons, including the financial crisis and low oil prices.

"The Silk Road is one of the most important areas of cooperation between Iran and China until 2025, which may open a new chapter in economic relations", said Gholam Hossein Shafei, president of the Iranian Chamber of Commerce (Mohamed Building, 2018).

\section{Conclusions}

In this paper, we discussed the subject of China-Gulf political and economic relations over a period of time between 2001 and 2018. The volume of exchanges between China and GCC countries rose with observable sources.

The political relations between China and all countries bordering the Persian Gulf region: The GCC countries, Iraq, and Iran will show important indicators of China's direction to develop relations between it and the countries of the region.

Economically, indicators of the development of relations with the total of these countries are indicated by indicators, such as mutual trade, the volume of mutual investment, and the place of energy in bilateral trade.

The research ended up proving the silver that was launched from them, which achieved the goals from which they were launched.

As a conclusion, the relations between China and the Arab Gulf countries have tended to develop politically and economically. China has not developed unilateral relations among the countries bordering the Arabian Gulf. It has not developed relations with one or two countries in the Arabian Gulf; it is open to all Gulf countries.

\section{References}

Alekhlna, V., \& Naoyuki, Y. (2018). Impact of world oil prices on an energy exporting economy including monetary policy. ADBI Working Paper Series, No. 828. Asian Development Bank Institute, Tokyo, Japan.

Al-Haristani, M. S. (2005). Encyclopedia of the history of the Arabian Gulf. Amman: Dar Osama for Publishing and Distribution.

Boukhamsin, A. (2017). A fact that makes the economic relationship Saudi Arabia Chinese distinctive. Retrieved from https://www.alarabiya.net

Cai, P. (2017). Understanding China's Belt and Road Initiative. The Lowy Institute for International Policy, March 4-6.

Chen, J. (2011). The emergence of China in the Middle East. Institute for National Strategic Studies (INSS) Strategic Forum, (271), 6 .

China International Network Website. (2018). Report: UAE, China expand trade and cultural ties after Chinese president's visit. Retrieved from http://www.china.org.cn/txt/2018-09/25/content_64017219.htm

China-Arab Cooperation Forum. (2018a). The seminar on China-Arab relations and dialogue between the Chinese and Arab civilizations. Retrieved from http://www.chinaarabcf.org/eng/jzjs/wmdhyths/

${ }^{6}$ China-Arab Cooperation Forum, Middle East Studies Institute, Shanghai University of International Studies, Shanghai, Beijing, May 3, 2018, at: http://www.lb.china-embassy.org/eng/xwdt/P020180620636385664840.doc. 
China-Arab Cooperation Forum. (2018b). China's ambassador to Doha: China is committed to building international relations in a new style. Retrieved from http://www.chinaarabcf.org/eng/zagx/yyzs/t1598915.htm

Faria, J. R., Mollick, A. V., Albuquerque, P. H., \& León-Ledesma, M. A. (2016). China's exports and the oil price. Research Papers in Economics, (14), 26.

Free Space. (2017). Report: Saudi Arabia and China plan to establish a \$20 billion investment fund. Retrieved from https://www.alhurra.com/a/saudi-arabia-china-investment/386873.html

Huakham, H. (2002). History of China: From prehistory until the twentieth century. (A. M. Kilani, Trans.). Cairo: Supreme Council of Culture.

Leung, G. C. K., Li, R., \& Low, M. (2011). Transitions in China's oil economy, 1990-2010. Eurasian Geography and Economics, $52(4), 486$.

Liu, Z. M. (2016). The historical development of Gulf-China relations. Retrieved from http://lasirener.com/84

Makhieber, S. F. (2008). Sino-Soviet relations 1949-1976. Tikrit University Journal of Humanities, (11), 491-492.

Makram Belawi, M. (2017). The initiative of the belt and the Chinese road and the inevitability of Arab geography. Al Jazeera Net. Retrieved from http://www.aljazeera.net/knowledgegate/opinions/2017/10/7/

Mohamed Building. (2018). Between Iran and China: Mysterious business horizons. Retrieved from https://kitabat.com/news/

Nibluk, T. (2017). China's emergence as the largest trading partner of the Gulf States. The Future of the Arab Magazine, (460), 81-82.

People's Daily Online. (2018a). Eighth Ministerial Meeting of the China-Arab Cooperation Forum. Retrieved from http://www. people.com.cn/n3/2018/0615/c31660-9472037.htm

People's Daily Online. (2018b). Report: China's Baidu satellite navigation system receives two new members in space. Retrieved from http://www.people.com.cn/n3/2018/0330/c31657-9443813.htm

Skynews, A. (2018). Report: Chinese president arrives in UAE for "historic visit". Retrieved from www.skynewsarabia.com/ middle-east/1165616

Sun, D. G. (2017). China and Middle East security governance. The Arab Future Journal, (461), 92-92, 101-102.

The World Trade Organization. (2018). World trade statistical review 2017. Geneva: World Trade Organization.

Xinhuanet. (2018). New Silk Road, the location of the channel and the road. Retrieved from http://www.xinhuanet.com/ silkroad/arabic/index.htm 